\title{
Geophysical and Geotechnical Investigations of a Landslide in Kekem Area, Western Cameroon
}

\author{
Pouyon Dieudonné Epada, ${ }^{1,2 *}$, Ganno Sylvestre ${ }^{3}$, Tabod Charles Tabod ${ }^{1}$ \\ ${ }^{1}$ Laboratory of Geophysics, University of Yaounde I, Yaounde, Cameroon \\ ${ }^{2}$ National Civil Engineering Laboratory, Yaounde, Cameroon \\ ${ }^{3}$ Department of Earth Sciences, University of Yaoundé I, Yaounde, Cameroon \\ Email: *epada@yahoo.fr, sganno2000@yahoo.fr
}

Received March 3, 2012; revised April 9, 2012; accepted April 20, 2012

\begin{abstract}
Geophysical and geotechnical surveys were conducted in the Western Cameroon (Kekem area) following a landslide on argillaceous material in order to understand the triggering processes and mechanisms of this landslide and to assess the stability of the slope. The geophysical soundings consisting of vertical electrical soundings with the Schlumberger electrode array configuration were carried out to monitor the behaviour of electrical resistivity in the landslide. Geoelectrical data showed a zone of low resistivity values identified as a clayey sand-filled aquifer. This aquifer played an important role in the triggering process of the landslide. Geotechnical soundings showed that the aquifer had a thickness of $7.0 \mathrm{~m}$. The depth from the landslide crest level to the failure surface reached $3.0 \mathrm{~m}$ and $20.6 \mathrm{~m}$. Laboratory tests were then carried out in order to evaluate the cohesion of the soil and the angle of internal friction, and to calculate the safety factor in view of making a stability analysis. The laboratory results exhibited a soil with low consistency, almost doughy. The mean value of the safety factor (1.4) been lower than the slope stability coefficient (1.5), revealed that the slope is unstable, likely to know at any moment a reactivation of the slide. This study showed that electrical soundings coupled with geotechnical surveys are useful tools for the characterization of landslides.
\end{abstract}

Keywords: Landslide; Resistivity; Argillaceous Material; Basal Undercutting; Kekem; Cameroon

\section{Introduction}

Geophysical methods are more and more used for landslide investigations. Soil modifications due to ground movement generally lead to the change of physical parameters of the sub soil. The measure of these parameters can then be used to image the movement of the land mass and monitor its evolution. Two main situations can potentially occur: 1) the geophysical contrast is related to a lithological change $[1,2] ; 2)$ the movement takes place within a homogeneous geological layer, but alters its physical characteristics. In this case, the geophysical contrast exists between the moving mass and the unaffected consolidated mass [3-6]. The geophysical contrast is then related to the cumulated or individual effects of the mechanical dislocation, the alteration and/or the increase of water content. Geophysical surveys applied to ground movements can be used to estimate the lateral extent of the landslide, the depth to the failure surface [7,8]; and also to detect water in the active mass [9].

Landslides are regular in Western Cameroon, and

${ }^{*}$ Corresponding author. some of them often lead to human deaths; yet their causes are not sometimes well understood. In this paper, we analyze a landslide which occurred at Kekem (Western Cameroon) in 2007. The aim of this study is to understand the triggering processes and the mechanism of this landslide as well as examine the possibility of another landslide by seeking natural causes and anthropogenic factors. The methodology used is as follow:

- The study of the geological and geomorphological context of the site will provide useful information on the instability processes of the slope;

- The use of vertical electrical soundings with a Schlumberger array in order to monitor the behaviour of electrical resistivity in the sliding area and thus characterize the geological materials in the zone. Electrical resistivity is an interesting physical parameter to image contrasts between different geological units, or the variations of the fracturing rate within the same geological structure $[10,11]$.

- The use of geotechnical tests in order to define mechanical characteristics of the soils (cohesion, angle of internal friction, consistency index and plasticity index). 


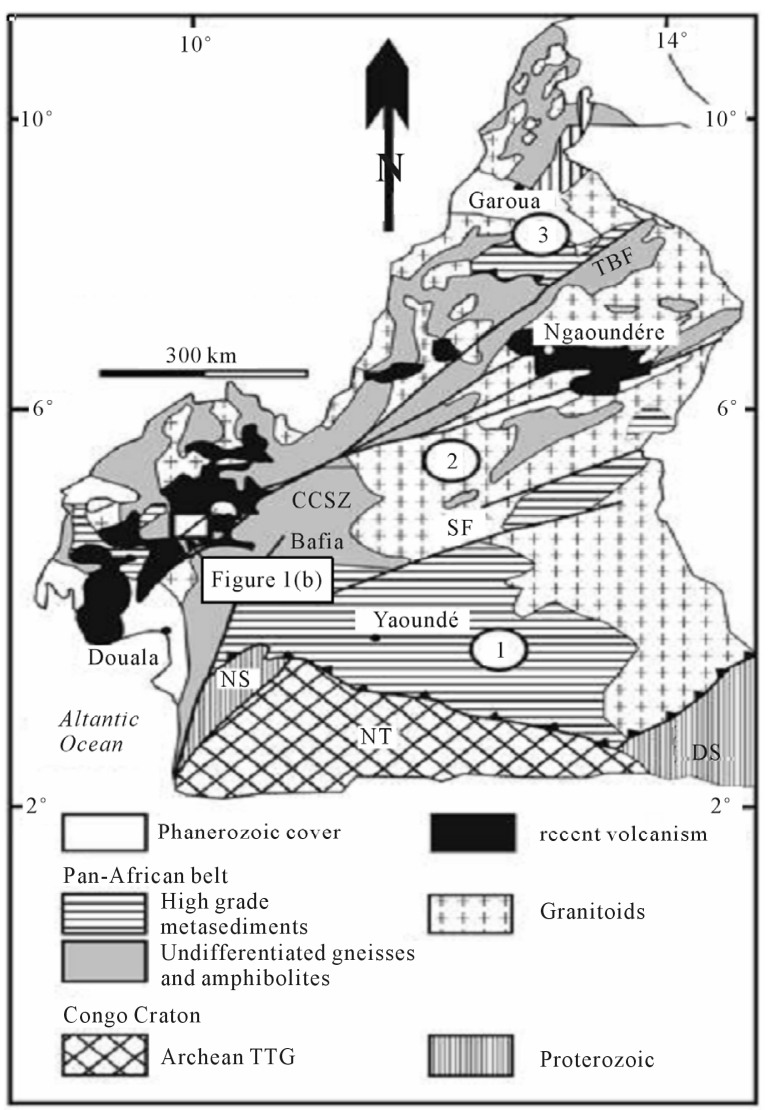

(a)

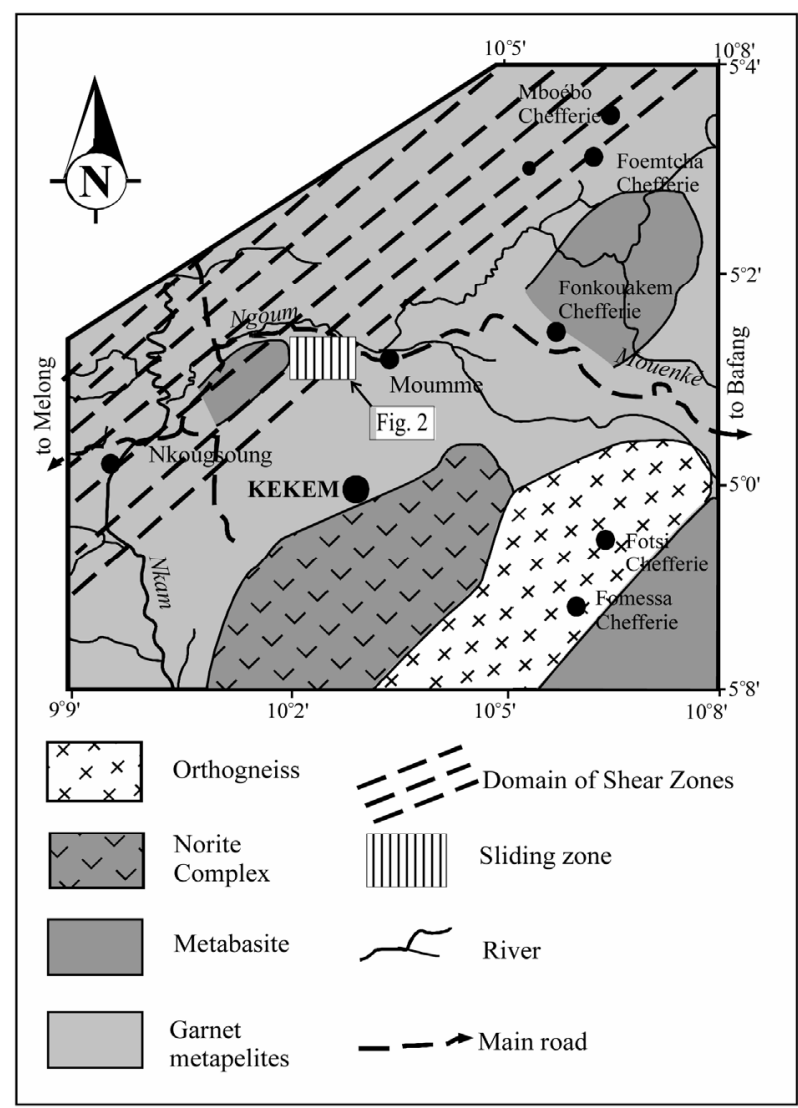

(b)

Figure 1. (a) Geological map of Cameroon with the three main domains of the Pan-African orogenic belt, from [24,28]. (1) southern domain corresponding to the Yaounde series thrusted onto the Congo Craton; (2) Central domain; (3) Northern domain; CCSZ: Central Cameroon Shear Zone; DS: Dja series; NS: Nyong series; NT: Ntem complex; SF: Sanaga fault; TBF: Tibati-Banyo Fault. Location of Kekem area is marked by a square; (b) Geological map of the Kekem area, modified from [28]. Sliding zone is represented by box.

\section{Geological Setting}

\subsection{Topographic Context}

The complex landslide which affected the hillslope of Jenbong (Kekem) occurred in a rough topographic context. This chaotic topography is marked by escarpments, cracks of regression upstream and dislocated blocks; a vegetation little dense and thinned out by places marked by trees, some dead, others tilted upstream. The hillslope is disturbed in its foot by a river (Ngoum) which draws meanders and carries on a strong erosive activity at the foot of the slope; it is thrown in the Nkam.

The crest of the slide which peaks in 2200 m roughly draws an arc of a circle. At its southeastern side, the slope has angle of $20 \%$. The northwestern side is steeper and has a convex slope, which is of the order of $54 \%$. The vertical distance between the crest and the foot of the hillslope is $57 \mathrm{~m}$. Under the summit, the northwestern side of the slope locally forms a quasi-circular catchment area. This catchment area gives rise to torrents which affect the superficial formations and contribute to notch the hillside of several meters (approximately $20 \mathrm{~m}$ ), forming a shredded landscape. The grounds of the slope are exploited, in particular the debris cones because of their fertility. At the top and all around the slope, are inhabited constructions; a clear growth of the population produces an intensification of the agro-pastoral activity and a widespread clearing. This strong agro-pastoral activity increases the risk of instability of the slope; until a recent past, ground movements of low magnitude were observed there.

\subsection{Lithologic Context}

In Cameroon, two main formations are distinguished: the Archean Congo Craton to the south and the Pan-African Belt to the north (Figure 1(a)). The Pan-African belt also known as Central African Fold Belt (CAFB) or Pan-African North Equatorial Fold Belt [12], is a Neoproterozoic orogen linked to the Trans-Saharan belt of western Africa and to the Braziliano Orogen of northeastern Brazil. The Neoproterozoic belt in Cameroon is subdivided 
into three main domains [13-17], from south to north (Figure 1(a)):

1) The southern domain comprises Neoproterozoic metasedimentary units, such as the Ntui-Betamba, Yaoundé and Mbalmayo units; the protoliths of these units were deposited in a passive margin environment at the northern edge of the Congo Craton and were metamorphosed under high $\mathrm{P}$ conditions at $616 \mathrm{Ma}[12,15,18]$. The rocks of this southern domain were thrusted onto the Archean Congo Craton towards the south [19]. The thrust continues towards the east, forming the Oubanguides Nappe in the Central African Republic;

2) The central domain is located between the Sanaga fault to the south and the Tibati-Banyo fault to the north. These large NE-striking transcurrent faults, as well as the Adamaoua fault inside the central domain, are regarded as possible prolongations of the major shear zones of NE Brazil in a pre-drift Gondwana reconstruction [20]. This central domain consists of archean to paleoproterozoic high-grade gneisses intruded by widespread Neoproterozoic syntectonic plutonic rocks of high-K calc-alkaline affinities [13,14,17,21-26];

3) The northern domain consists of subordinate 830 Ma-old metavolcanics of tholeiitic and alkaline affinities associating with metasediments known as the Poli series. Widespread 630 - 660 Ma-old calc-alkaline granitoids, presently orthogneissified, result from a major episode of crustal accretion. A Paleoproterozoic crustal source in this region is attested by the presence of 2-Ga old inherited zircons in the granitoids [27].

The study area (Kekem) is located to the southwestern part of the central domain (Figure 1(b)). Recent works $[28,29]$ distinguished two lithologic associations: a metamorphic unit intruded by magmatic complex. The metamorphic unit is composed of metabasites (mainly garnetpyroxene gneisses, amphibolites and pyroxenites) and metasediments (mainly garnet-biotite/sillimanite gneisses, garnet-biotite gneisses). All these rocks outcrop as inselberg, flagstones, lenses or boudins. Granoblastic textures prevail in all rock types, although flaser and mylonitic ones are also commonly observed. It records a first phase of deformation $\mathrm{D}_{1}$ of tangential tectonics with pressure peak of a prograde metamorphism developed in the high temperature amphibolites facies conditions $\left(720^{\circ} \mathrm{C} / 12\right.$ Kbars $-750^{\circ} \mathrm{C} / 7$ Kbars; [29]). The magmatic unit comprises more or less orthogneissified granitoids, which crop out close to shear zones characterizing the second phase of deformation $\mathrm{D}_{2}$ and were emplaced during $\mathrm{D}_{2}$, and post $\mathrm{D}_{2}$ granitoids (biotite- and amphibole-rich granites, two micas granites, monzodiorite, monzonite and norite). The second phase of deformation $\mathrm{D}_{2}$ is of transcurrent tectonics and took place between 580 to 560 $\mathrm{Ma}$ (U-Th-Pb monazite age, [28]). Structures of this phase transpose early $D_{1}$ structures and are coeval with granite emplacement.

\section{Morphology and Characteristics of the Sliding}

On October 20, 2007, towards the end of the great rainy season, a landslide occurred at Kekem on the National road No. 5 connecting Bafang to Melong (Western, Cameroon). This sliding took place exactly at a village called Jenbong. The slipped mass of earth covered a volume of about $30,000 \mathrm{~m}^{3}$ of materials, sweeping off road over a distance of close to $100 \mathrm{~m}$ and about $4 \mathrm{~m}$ deep, destroying houses and plantations, and killing one woman. It occurs in geological formations particularly sensitive to this type of movement because of the heterogeneity of their structure and the relative impermeability of some layers. The mass of materials put in motion has a length of about $152 \mathrm{~m}$ and a width of more than $53 \mathrm{~m}$ at the level of the crest of the sliding. It widens in its median part. The scar of wrenching shows a rejection of $5 \mathrm{~m}$ of height. A series of streaks notched in the clays testify to the traction which affected the ground. The intense fracturing of the clayey benches causes the detachment of some pieces of rocks and provokes crumblings which continue to feed the body of the sliding. The body of the sliding is constituted by a mass of chaotic materials. Under a lateritic cover of 1 to $2 \mathrm{~m}$, are greyish clays encrusted with blocks of granitic rock more or less altered of variable size, some being able to reach 2 to $3 \mathrm{~m}$ of diameter. From the head of the sliding to the median part, a series of secondary fractures, rejections less important than the main steep slope, gives to the body of the sliding a structure in steps. These steps have a surface weakly tilted towards the hillslope. Given the absence of channels drainage, the secondary fractures in counterslope allow the accumulation of rainwater, which gives to these steps a muddy environment during the rainy season. The affected area covers a surface of approximately 19.8 hectare. In September 2008, a mudslide was observed at the same place

\section{Methods}

\subsection{Geoelectrical Soundings}

Three vertical electrical soundings $S_{1}, S_{2}$ and $S_{3}$ were carried out using a Schlumberger array (Figure 2). All profiles are almost parallel to the direction of the slide. Directions of expansion and the length of profiles were constrained by topography; there was only one direction in which electrodes could be taken a sufficient distance in a straight line. The geoelectrical apparatus used for this campaign was the resistivimeter TERRATEST TT 800. The data processing and inversion were made using GeoElect.Mod. This software uses the Gosh [30] linear 




Figure 2. Map of the sliding zone and location of geoelectrical soundings and penetrometer tests.

digital filter.

\subsection{Geotechnical Tests}

\section{1) In situ tests}

Thirty four (34) tests using the heavy dynamic penetrometer were carried out. Ten (10) sampling manual wells were dug on the stable part of the slope in order to take undisturbed soil samples. The heavy dynamic penetrometer test enables to appreciate the soil resistance and is useful to determine the depth to the failure surface and the aquifer thickness. Undisturbed soils samples taken from the wells were used for physical and mechanical purposes in the laboratory.

\section{2) Laboratory tests}

Lab tests were carried out on the undisturbed samples taken from the manual wells in order to determine the cohesion of the soil and the angle of internal friction and to calculate the safety factor to evaluate the stability of the slope. The adopted method of calculation is that of Fellenius because it underestimates the value of the factor of safety and thus goes in the direction of safety. The hillslope of Jenbong (Kekem) having already been the subject of several ground movements, the minimum design slope stability coefficient was taken equal to 1.5 because of the strong susceptibility to landslides which 
this slope presents, and thus high risk that it induces by causing damage and loss of lives. The following tests were then carried out:

- Atterberg limits $w_{L}$ and $w_{P}$ the purpose of which is to define the states of moisture corresponding to the limits between the four states of the ground (solid, semi-solid, plastic and liquid). The consistency and behaviour in each state of the soil are different, and so are its mechanical properties. The boundary between each state can be defined based on a change in the soil's behaviour. The liquid limit $w_{L}$ is the water content where a soil changes from plastic to liquid behaviour, plastic limit $w_{P}$ is the water content where a soil starts to exhibit plastic behaviour. These characteristics are supplemented by the plasticity in$\operatorname{dex} I_{P}=w_{L}-w_{P}$ which characterizes the state of plasticity of a soil. It is the size of the range of water content where the soil exhibits plastic properties [31]. Atterberg limits $w_{L}$ and $w_{P}$ are useful parameters for clayey soils.

- Consistency index $I_{c}$ (this index informs about the consistency of a soil): $I_{c}=\frac{w_{L}-w_{P}}{I_{P}}$ where $w$ represents the natural water content of a soil.

For the penetrometer tests (Spd) the sliding area was divided into two zones because of the topography of the site.

\section{Results and Discussion}

\subsection{Results}

Geoelectrical soundings results are given in the Tables 1-3. The resistivity curves (Figures 3(a)-(c)) obtained from the geoelectrical data gave a three layered earth model:

1) A conductive surface layer of about $90 \mathrm{~cm}$ of thickness (resistivity $\rho$ varies from $80 \Omega \cdot \mathrm{m}$ to $160 \Omega \cdot \mathrm{m}$ ).

2) An intermediate layer of lower resistivity $(50 \Omega \cdot \mathrm{m}$ to $180 \Omega \cdot \mathrm{m}$ ) and thickness varying from $2.0 \mathrm{~m}$ to $7.0 \mathrm{~m}$. Its low resistivity indicates the presence of an aquifer. Geotechnical soundings and geological investigations identified this zone as a clayey sand-filled fractured reservoir. Hydrodynamic characteristics of this aquifer are the following: effective porosity: $14 \%$; hydraulic conductivity: $2 \times 10^{-8} \mathrm{~m} / \mathrm{s}$; average transmissivity: $13 \times 10^{-8}$ $\mathrm{m}^{2} / \mathrm{s}$.

3) A deep relatively resistant layer $(250 \Omega \cdot \mathrm{m}$ to 400 $\Omega \cdot \mathrm{m})$ with a thickness varying from $2.5 \mathrm{~m}$ to $18.0 \mathrm{~m}$ lying on a granito-gneissic basement $(\rho>1000 \Omega \cdot \mathrm{m})$.

Geotechnical soundings showed that the depth to the failure surface varies between $3.0 \mathrm{~m}$ and $20.6 \mathrm{~m}$. In addition, these tests confirmed the aquifer thickness of $7.0 \mathrm{~m}$.

The analysis of the results of the laboratory tests carried out on the undisturbed samples taken on the site
Table 1. (a) Earth configuration of P1; (b) Measured and computed data along $P 1$.

(a)

\begin{tabular}{ccc}
\hline Layer No & Resistivity (Ohm-m) & Thickness (m) \\
\hline 1 & 160 & 0.6 \\
2 & 180 & 2.0 \\
3 & 130 & 3.0 \\
4 & 400 & 2.0 \\
5 & 60 & 6.5 \\
6 & 400 & 6.0 \\
7 & 1000.00 & Infinity \\
\hline
\end{tabular}

(b)

\begin{tabular}{ccc}
\hline \multicolumn{2}{c}{ Apparent resistivity } \\
\hline $\mathbf{A B} / 2(\mathrm{~m})$ & Measured (Ohm-m) & Computed (Ohm-m) \\
\hline 1.0 & 158.71 & 164.57 \\
2.0 & 197.30 & 170.65 \\
3.0 & 94.51 & 171.26 \\
4.0 & 159.26 & 169.00 \\
5.0 & 150.87 & 166.42 \\
7.0 & 174.36 & 163.34 \\
10.0 & 154.53 & 161.87 \\
15.0 & 256.87 & 159.79 \\
20.0 & 166.71 & 160.63 \\
25.0 & 116.81 & 167.16 \\
30.0 & 147.26 & 178.72 \\
35.0 & 181.64 & 193.65 \\
40.0 & 211.37 & 210.49 \\
50.0 & 251.02 & 246.20 \\
60.0 & 299.49 & 281.54 \\
80.00 & 311.11 & 346.41 \\
110.00 & 449.46 & 428.43 \\
\hline
\end{tabular}

emphasizes that the remained movable ground from there after the sliding is a rather compressible deteriorated rock and whose mechanical characteristics in the short run (the angle of internal friction $\varphi_{u}$ and the cohesion $C_{u}$ ), vary respectively from $24^{\circ}$ to $32^{\circ}$ and from 0.013 to 0.19 bar. These results suggest materials with low cohesion.

The measurement of the Atterberg limits yielded the following values: $w_{L}: 79 \% ; w_{P}: 42 \%$, which made it possible to have a plasticity index $I_{P}$ of $37 \%$, the ground in place thus consists of a rather plastic clay. The 
Table 2. (a) Earth configuration of P2; (b) Measured and computed data along $\mathbf{P} 2$.

(a)

\begin{tabular}{ccc}
\hline Layer No & Resistivity (Ohm-m) & Thickness (m) \\
\hline 1 & 80 & 0.6 \\
2 & 160 & 0.9 \\
3 & 70 & 3.0 \\
4 & 400 & 2.5 \\
5 & 150 & 7.0 \\
6 & 5000 & infinity \\
\hline
\end{tabular}

(b)

\begin{tabular}{|c|c|c|}
\hline \multirow[b]{2}{*}{$\mathbf{A B} / 2(\mathrm{~m})$} & \multicolumn{2}{|c|}{ Apparent resistivity } \\
\hline & Measured (Ohm-m) & Computed (Ohm-m) \\
\hline 1.0 & 81.63 & 93.37 \\
\hline 2.0 & 142.20 & 108.60 \\
\hline 3.0 & 114.12 & 110.44 \\
\hline 4.0 & 126.68 & 108.83 \\
\hline 5.0 & 140.82 & 108.72 \\
\hline 7.0 & 169.13 & 115.34 \\
\hline 10.0 & 143.23 & 134.17 \\
\hline 15.0 & 194.84 & 169.28 \\
\hline 20.0 & 293.02 & 204.46 \\
\hline 25.0 & 203.10 & 240.78 \\
\hline 30.0 & 260.97 & 278.41 \\
\hline 35.0 & 302.47 & 316.92 \\
\hline 40.0 & 316.12 & 355.82 \\
\hline 50.0 & 415.01 & 433.48 \\
\hline 60.0 & 424.49 & 509.78 \\
\hline 80.00 & 588.49 & 656.54 \\
\hline 110.00 & 768.30 & 862.11 \\
\hline
\end{tabular}

value of the consistency index $\left(I_{c}=0.35\right)$ testifies to a not very consistent soil, almost doughy.

The calculation of the stability of this slope from the geomechanical characteristics of the soil led to a mean safety factor equal to 1.4 , lower than the slope stability coefficient.

\subsection{Discussion: The Triggering Systems of the Kekem landslide}

Three major factors (meteorological conditions, geological factors and anthropogenic causes) triggered the Kekem
Table 3. (a) Earth configuration of P3; (b) Measured and computed data along P3.

(a)

\begin{tabular}{ccc}
\hline Layer No & Resistivity (Ohm-m) & Thickness (m) \\
\hline 1 & 130 & 4.5 \\
2 & 50 & 2.0 \\
3 & 120 & 5.0 \\
4 & 250 & 18.0 \\
5 & 7000 & Infinity \\
\hline
\end{tabular}

(b)

\begin{tabular}{|c|c|c|}
\hline \multirow[b]{2}{*}{$\mathbf{A B} / 2(\mathrm{~m})$} & \multicolumn{2}{|c|}{ Apparent resistivity } \\
\hline & Measured (Ohm-m) & Computed (Ohm-m) \\
\hline 1.0 & 81.63 & 93.37 \\
\hline 2.0 & 142.20 & 108.60 \\
\hline 3.0 & 114.12 & 110.44 \\
\hline 4.0 & 126.68 & 108.83 \\
\hline 5.0 & 140.82 & 108.72 \\
\hline 7.0 & 169.13 & 115.34 \\
\hline 10.0 & 143.23 & 134.17 \\
\hline 15.0 & 194.84 & 169.28 \\
\hline 20.0 & 293.02 & 204.46 \\
\hline 25.0 & 203.10 & 240.78 \\
\hline 30.0 & 260.97 & 278.41 \\
\hline 35.0 & 302.47 & 316.92 \\
\hline 40.0 & 316.12 & 355.82 \\
\hline 50.0 & 415.01 & 433.48 \\
\hline 60.0 & 424.49 & 509.78 \\
\hline 80.00 & 588.49 & 656.54 \\
\hline 110.00 & 768.30 & 862.11 \\
\hline
\end{tabular}

landslide:

\section{1) Meteorological conditions}

This landslide occurred in the course of the rainy season, after intense precipitations. These precipitations decreased the cohesion of the soil materials by the wetting of the soil matrix [32]. Heavy rains that fell during the months of September and October caused deep imbibetions of clay materials of the slope and triggered in an instantaneous and brutal way the moving of a considerable quantity of materials.

\section{2) Geological factors}

Here lie a number of factors: the structure and the lithology of the slope, and the geotechnical nature of 


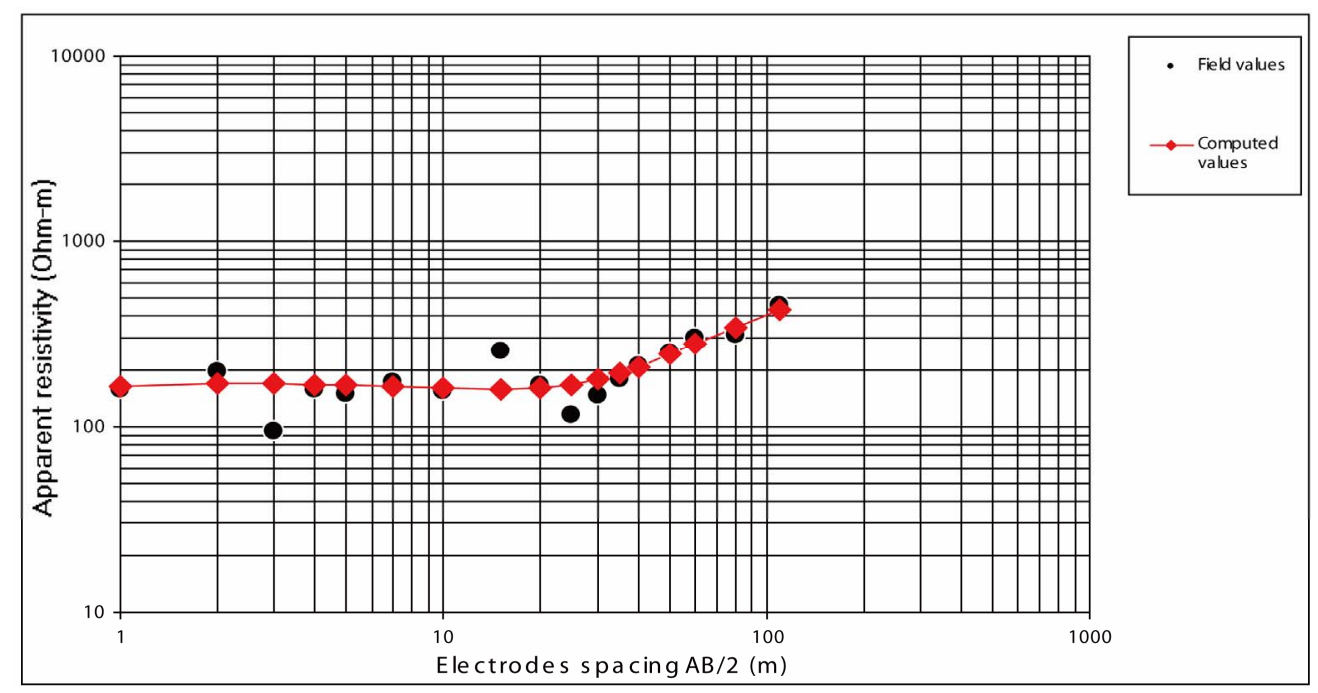

(a)



(b)

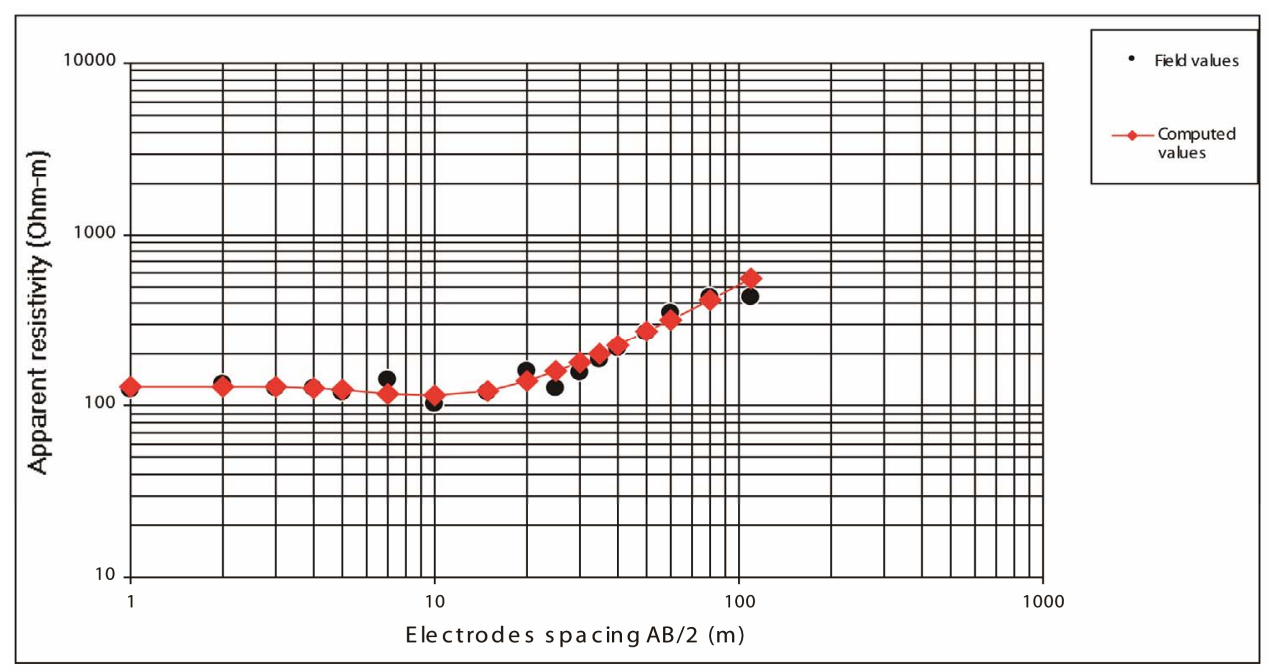

(c)

Figure 3. Resistivity curves of VES1 (a), VES 2 (b) and VES 3 (c). 
affected materials as well as the dynamics of the river Ngoum.

The soil in the landslide zone is mainly argillaceous. Clays deteriorate generally only on very low thicknesses because of their impermeability. On tilted slopes, they deteriorate all the more quickly as the factors determining the permeability are active [33]: low cohesion, porosity, the density of the slits of withdrawal due to the regular alternation of moistening during the rainy season and deep desiccation during the dry season [34]. The material thus mobilized is subjected to erosion. After a short transport on the slope, a part accumulates at the bottom of the slope. The abundance of clays in materials of the slope has effects on stability according to their geotechnical and mineralogical characteristics. Indeed, as soon as the water content of clays exceeds the content of confined water and that the free water appears the resistance of materials falls. They pass from a solid state in a plastic state then to a liquid state. The density of the fracturing in a tilted gneiss material created weak zones which accelerated infiltration of water and the imbibitions of the clayey levels. These litho-structural conditions combined to a high slope angle of $54 \%$, contributed to the destabilization of the slope and to the triggering of the landslide.

The intense undercutting of the foot of the slope by the Ngoum River contributed to the destabilization of the slope and so facilitated the landslide at Kekem. The hydrodynamic activity of this river was intensified by the important contributions of water, caused by the strong rains which fell in the area. This activity accentuated the stiffness of the slope to the foot of the slope. The call to the vacuum created by the undercutting of the base of the slope accelerated the slide.

\section{3) Anthropogenic causes}

The human activity contributed to the triggering of the landslide at Kekem in two ways: 1) the cultivating of these steep slopes renders the topmost layers of the earth loose and increase the rate of water infiltration; 2) the existence of a major carrying heavy traffic frequently provoked vibrations of the loose soil cover on the slope thus favoring the occurrence of the landslide.

\section{Conclusions}

The aim of this paper was to determine the triggering mechanisms of the Kekem landslide. The geoelectric study revealed zones of clayey sand-filled fractures and a spatial distribution of materials with argillaceous prevalence. Penetrometer surveys confirmed the presence of these fractures and the aquifer. These results made it possible to determine the depth to the failure surface; from the landslide crest level, it varies between $3.0 \mathrm{~m}$ and $20.6 \mathrm{~m}$. The results of the laboratory tests showed a ground with low cohesion, not very consistent and rather compressible. The causes of the sliding of Kekem are varied: they are internal and external. The internal causes are the characteristics specific to the slope. It is about lithology, the structural disposition and the value of the angle of the slope. The external factors as for them destabilize by their actions the internal structures of the formations of the slope and cause their movement. It is of the climate, basal undercutting and the anthropogenic action. Water is the worsening factor of the landslides; it is the engine and the catalyst of the majority of the actions of the other factors. Under the action of water, the mechanical deformation of clays which form the dominant fraction of the geological units of the slope is the main cause. The geological formations rich in clays are generally impermeable with water, however, the structural disposition and the human intervention amplified the density of the zones of weakness which allowed an in-depth imbibitions. When all the factors are present, only gravity is required to provoke the sliding. This action of gravity was facilitated by basal undercutting by the river Ngoum at the foot of the hill.

For the stability study of this slope, the safety factor was calculated and found to have an average value of 1.4. This value, been smaller than the adopted value of the slope stability coefficient (1.5), revealed that the zone is unstable; likely to experience some disorders at any time. The disposition and the aspect of the body of the sliding support its reactivation. The crest of the slope favors the accumulation of rain waters. The infiltration and the percolation of water by the plans of fractures which have a strong hydraulic conductivity can play a part of lubricant for the handing-over moving and the reactivation of the sliding. It is a slower phase and less spectacular, sometimes unperceivable, but it is a latent instability which always constitutes a risk in the event of precipitations similar to those which triggered it. It is what explains the mudslide observed one year after the sliding.

This work shows that electrical soundings coupled with geotechnical surveys are useful tools for the characterization of landslides.

\section{Acknowledgements}

The authors thank the National Civil Engineering Laboratory (LABOGENIE) for providing the equipment used to carry out this study. The first author thanks $\mathrm{Mr}$. NGAH OWONO Jules (Civil Engineer) for his contribution to the processing and the interpretation of geotechnical data.

\section{REFERENCES}

[1] T. Glade, P. Stark and R. Dikau, "Determination of Potential Landslide Shear Plane Depth Using Seismic Refraction-A Case Study in Rheinhessen, Germany," Bul- 
letin of Engineering Geology and the Environment, Vol. 64, No. 2, 2005, pp. 151-158. doi:10.1007/s10064-004-0258-1

[2] V. Agnesi, M. Camardab, C. Conoscentia, A. Di Maggio, I. Dilibertoc, P. Madoniac and E. Rotiglianoa, "A Multidisciplinary Approach to the Evaluation of the Mechanism That Triggered the Cerda Landslide (Sicily, Italy)," Geomorphology, Vol. 65, No. 1-2, 2005, pp. 101-116. doi:10.1016/j.geomorph.2004.08.003

[3] J. P. T. Caris and Th. W. J. Van Asch, "Geophysical, Geotechnical and Hydrological Investigations of a Small Landslide in the French Alps," Engineering Geology, Vol. 31, No. 3-4, 1991, pp. 249-276.

[4] V. Lapenna, P. Lorenzo, A. Perrone, S. Piscitelli, E. Rizzo and F. Sdao, "2D Electrical Resistivity Imaging of Some Complex Landslides in Lucanian Apennine Chain, Southern Italy," Geophysics, Vol. 70, No. 3, 2005, pp. 1118. doi:10.1190/1.1926571

[5] T. Lebourg, S. Binet, E. Tric, H. Jomard and S. El Bedoui, "Geophysical Survey to Estimate the 3D Sliding Surface and the 4D Evolution of the Water Pressure on Part of a Deep Seated Landslide," Terra Nova, Vol. 17, No. 5, 2005, pp. 399-406. doi:10.1111/j.1365-3121.2005.00623.x

[6] V. Bogoslovsky and A. Ogilvy, "Geophysical Methods for the Investigation of Landslide," Geophysics, Vol. 42, No. 3, 1977, pp. 562-571. doi:10.1190/1.1440727

[7] D. Cummings and B. R. Clark, "Use of Seismic Refraction and Electrical Resistivity Surveys in Landslide Investigations," Bulletin of the Association of Engineering Geologists, Vol. 25, No. 4, 1998, pp. 459-464.

[8] F. Bruno and F. Marillier, "Test of High-Resolution Seismic Reflection and Other Geophysical Techniques on the Boup Landslide in the Swiss Alps," Surveys in Geophysics, Vol. 21, No. 4, 2000, pp. 333-348. doi:10.1023/A:1006736824075

[9] H. J. Mauritsch, W. Seiberl, R. Arndt, A. Romer, K. Schneiderbauer and G. P. Sendlhofer, "Geophysical Investigations of Large Landslides in the Carnic Region of Southern Austria," Engineering Geology, Vol. 56, No. 3-4, 2000, pp. 373-388. doi:10.1016/S0013-7952(99)00120-9

[10] O. Meric, "Etude de Mouvements de Terrain par Méthodes Géophysiques," Ph.D. Thesis, Joseph Fourier University, Grenoble, 2006.

[11] J. P. Nzenti, "Pétrogenèse des Migmatites de Yaoundé (Cameroun): Eléments Pour un Modèle Géodynamique de la Chaîne Pan-Africaine Nord-Equatoriale," Thèse Nouveau Doctorat, University of Nancy I, Lorraine, 1987.

[12] J. P. Nzenti, P. Barbey, J. M. Bertrand and J. Macaudière, "La Chaîne Panafricaine au Cameroun: Cherchons Suture et Modèle," 15ème Réunion des Sciences de la Terre, Abstract, Nancy, 26-28 Avril 1994.

[13] J. P. Nzenti, B. Kapajika, G. Wörner and R. T. Lubala, "Synkinematic Emplacement of Granitoids in a Pan-African Shear Zone in Central Cameroon," Journal of African Earth Sciences, Vol. 45, No. 1, 2006, pp. 74-86. doi:10.1016/j.jafrearsci.2006.01.005
[14] T. Ngnotué, J. P. Nzenti, P. Barbey and F. M. Tchoua, "The Ntui-Betamba High Grade Gneisses: A Northward Extension of the Pan-African Yaoundé Gneisses in Cameroon," Journal of African Earth Sciences, Vol. 31, No. 2, 2000, pp. 369-381.

[15] V. Ngako, P. Affaton, J. M. Nnange and T. Njanko, "Pan-African Tectonic Evolution in Central and Southern Cameroon: Transpression and Transtension during Sinistral Shear Movements," Journal of African Earth Sciences, Vol. 36, 2003, pp. 207-214. doi:10.1016/S0899-5362(03)00023-X

[16] E. L. Tanko Njiosseu, J. P. Nzenti, T. Njanko, B. Kapajika and A. Nédelec, "New U-Pb Zircon Ages from Tonga (Cameroon): Coexisting Eburnean-Transamazonian $(2.1 \mathrm{Ga})$ and Pan-African (0.6 Ga) Imprints," Comptes Rendus Géosciences, Vol. 337, No. 16, 2005, pp. 551562. doi:10.1016/j.crte.2005.02.005

[17] J. Penaye, S. F. Toteu, W. R. Van Schmus and J. P. Nzenti, "U-Pb and Sm-Nd Preliminary Geochronology Data on the Yaoundé Series, Cameroon: Re-Interpretation of the Granulitic Rocks as the Suture of Collision in the Centrafrican Belt," Comptes Rendus de l'Académie des Sciences de Paris, Vol. 317, No. 6, 1993, pp. 789-794.

[18] J. P. Nzenti, P. Barbey, P. Jegouzo and C. Moreau, "Un Nouvel Exemple de Ceinture Granulitique Dans une Chaîne Protérozoïque de Transition: Les Migmatites de Yaoundé au Cameroun," Compte Rendu Académie des Sciences de Paris, Vol. 299, No. 17, 1984, pp. 1197-1199.

[19] C. Castaing, J. L. Feybesse, D. Thieblemont, C. Triboulet and P. Chevremont, "Paleogeographical Reconstructions of the Pan-African/Brasiliano Orogen: Closure of an Oceanic Domain or Intracontinental Convergence between Major Blocks," Precambrian Research, Vol. 69, 1995, pp. 327-344. doi:10.1016/0301-9268(94)90095-7

[20] C. Nzolang, H. Kagami, J. P. Nzenti and F. Holz, "Geochemistry and Preliminary Sr-Nd Isotopic Data on the Neoproterozoic Granitoids from the Bantoum Area, West Cameroon: Evidence for a Derivation from a Paleoproterozoic to Archean Crust," Polar Geoscience, Vol. 16, 2003, pp. 196-226.

[21] M. L. Djouka-Fonkwe, B. Schulz, J. P. Tchouankoué and C. Nzolang, "Geochemistry of the Bafoussam Pan-African I- and S-type Granitoids in Western Cameroon," Journal of African Earth Sciences, Vol. 50, No. 2-4, 2008, pp. 148-167. doi:10.1016/i.jafrearsci.2007.09.015

[22] A. Nzina Nchare, J. P. Nzenti, E. L. Tanko Njiosseu, S. Ganno and T. Ngnotué, "Synkinematic Ferro-Potassic Magmatism from the Mekwene-Njimafofire Foumban Massif, along the Foumban-Banyo Shear Zone in Central Domain of Cameroon Pan-African Fold Belt," Journal of Geology and Mining Research, Vol. 2, No. 6, 2010, pp. 142-158.

[23] C. Chebeu, C. D. Ngo Nlend, J. P. Nzenti and S. Ganno, "Neoproterozoic High-K Calc-Alkaline Granitoids from Bapa-Batié, North Equatorial Fold Belt, Central Cameroon: Petrogenesis and Geodynamic Significance," The Open Geology Journal, Vol. 5, 2011, pp. 1-20. doi:10.2174/1874262901105010001

[24] A. A. Ganwa, W. Frisch, W. Siebel, G. E. Ekodeck, C. K. 
Shang and V. Ngako, "Archean Inheritances in the Pyroxene-Amphibole-Bearing Gneiss of the Méiganga Area (Central North Cameroon): Geochemical and $\mathrm{Pb} / \mathrm{Pb}$ Age Imprints," Comptes Rendus Geosciences, Vol. 340, No. 4, 2008, pp. 211-222. doi:10.1016/j.crte.2007.12.009

[25] A. A. Ganwa, W. Siebel, C. K. Shang, N. Seguem and G. E. Ekodeck, "New Constraints from Pb-Evaporation Zircon Ages of the Méiganga Amphibole-Biotite Gneiss, Central Cameroon, on Proterozoic Crustal Evolution," International Journal of Geosciences, Vol. 2, 2011, pp. 138-147.

[26] S. F. Toteu, A. Michard, J. M. Bertrand and G. Rocci, "U/Pb of Precambrian Rocks from Northern Cameroon, Orogenic Evolution and Chronology of the Pan-African Belt of Central Africa," Precambrian Research, Vol. 37, No. 1, 1987, pp. 71-87. doi:10.1016/0301-9268(87)90040-4

[27] D. Tchaptchet Tchato, B. Schulz and J. P. Nzenti, "Electron Microprobe (EMP) Monazite Dating and P-T Data of the Neoproterozoic Metamorphic and Mylonitic Events in the Kekem Area, Cameroon North Equatorial Fold Belt," Neues Jahbur of Paleontology, Vol. 186, No. 1, 2009, pp. 95-109.

[28] D. T. Tchato, J. P. Nzenti, E. L. Tanko Njiosseu, T. Ngnotué and S. Ganno, "Neoproterozoic Metamorphic Events in the Kekem Area (Central Domain of the Cameroon North Equatorial Fold Belt): P-T Data," Journal of Cameroon Academy of Sciences, Vol. 8, No. 2-3, 2009, pp. 91-106.

[29] D. P. Gosh, "Inverse Filter Coefficients for the Computation of Apparent Resistivity Standard Curve for Horizontal Stratified Earth Geophysics," Prospectives, Vol. 19, 1971, pp. 769-775.

[30] J. Costet and G. Sanglerat, "Cours Pratique de Mécanique des Sols (Deuxième Edition)," Tome I, Dunod, Paris, 1975.

[31] Th. Van Asch, W. J. J. Buma and L. P. H. Van Beek, “A View on Some Hydrological Triggering Systems in Landslides," Geomorphology, Vol. 30, No. 1-2, 1999, pp. 25- 32. doi:10.1016/S0169-555X(99)00042-2

[32] A. Faleh and A. Sadiki, "Glissement Rotationnel de Dhar El Harrag: Exemple d'Instabilité de Terrain Dans le Prérif Central (Maroc)," Bulletin de l'Institut Scientifique, Rabat, Section Sciences de la Terre, No. 24, 2002, pp. 41-48.

[33] M. Borie, A. Marache, M. Frappa, J-F. Lataste, J. Riss and R. Fabre, "Application de la Méthode Electrique à l'Etude de la Stabilité de la Falaise Rocheuse des Viviers-Basques (64, Urrugne): Détermination de la Structure du Massif Rocheux et des Conditions Hydrauliques," Conference Proceeding, Journées AGAP, Lyon, 27-28 October 2004, pp. 34-37.

[34] P. Mouroux, P. Margron and J. C. Pinte, "La Construction Economique sur Sols Gonflants," Edition BRGM, Paris, 1988. 